\title{
Heritage Preservation Education: Teachers' Preconceptions and Teachers Implementation in Visual Arts Classes
}

ROBERT POTOČNIK

$\approx$ In Slovenia, teachers of the school subject visual arts (implemented at the primary level by primary school teachers and at secondary level by fine visual arts teachers) play a significant role in planning and implementing visual arts tasks with preservation concepts. With these activities, they can raise awareness of cultural heritage meaning, strengthening the nation's cultural identity. Pupils should develop into active and responsible citizens who are able to understand heritage problems in general and express their sensitivity and respect for their cultural heritage and its preservation. The main purpose of this paper is to identify the teachers' preconceptions about the preservation of architecture in the Slovenian countryside and the implementation of heritage preservation concepts in visual arts teaching. Altogether, 125 teachers from Slovenia participated in this study. The research revealed the teachers' preconceptions regarding some problems in the Slovenian countryside, as well as sufficient awareness of the importance of the implementation in heritage preservation concepts in visual arts activities, according to contemporary professional guidelines. Teachers' preconceptions reveal a lack of some basic knowledge of preservation concepts, which lead us to compare the results with the current guidelines. It can be concluded that greater emphasis should be placed on developing training programmes for teachers with specific preservation concepts and didactic materials for students in the field of preservation education with the aim of developing the students' positive and responsible attitudes to those problems. More heritage preservation education content should be incorporated into pre- and in-service teachers' education, and teachers should develop competences to implement these topics into their teaching.

Keywords: visual arts education, heritage preservation education, preservation of architecture in the Slovenian countryside, teacher's preconceptions and implementation 


\section{Ozaveščanje o skrbi za kulturno dediščino: učiteljevo razumevanje in implementacija pri pouku likovne dejavnosti}

ROBERT POTOČNIK

$\propto$ Učitelji pouka likovne dejavnosti v osnovni šoli v Sloveniji (na razredni stopnji učitelji razrednega pouka in na predmetni stopnji likovni pedagogi) igrajo pomembno vlogo pri načrtovanju in izvajanju likovnih nalog z vsebinami skrbi za kulturno dediščino. S temi dejavnostmi lahko ozaveščajo o pomenu kulturne dediščine in krepijo nacionalno kulturno identiteto. Učence bi morali usmerjati, da v prihodnosti postanejo aktivni in odgovorni državljani, ki so sposobni razumeti težave ter izražati svojo občutljivost in spoštovanje do kulturne dediščine pa tudi skrbi zanjo. Glavni namen prispevka je ugotoviti učiteljevo razumevanje posebnosti skrbi za arhitekturno dediščino na slovenskem podeželju in implementacijo teh vsebin pri pouku likovne dejavnosti v osnovni šoli. V raziskavi je sodelovalo 125 slovenskih učiteljev. Poudarjena so nekatera razumevanja glede težav s skrbjo za kulturno dediščino na slovenskem podeželju pa tudi zadostno zavedanje pomena implementacije problematike skrbi za kulturno dediščino v okviru likovnih dejavnosti skladno s sodobnimi smernicami. Večji poudarek je treba nameniti usposabljanju učiteljev o skrbi za kulturno dediščino ter oblikovanju didaktičnih gradiv s ciljem ozaveščanja učencev o pozitivnem in odgovornem odnosu do skrbi za kulturno dediščino. Več vsebin o skrbi za kulturno dediščino je treba vključiti tudi v izobraževanje bodočih učiteljev in učiteljev v praksi s ciljem razvijanja kompetenc za vključevanje omenjene problematike v njihovo poučevanje.

Ključne besede: pouk likovne dejavnosti, ozaveščanje o skrbi za kulturno dediščino, skrb za arhitekturno dediščino slovenskega podeželja, učiteljevo razumevanje in implementacija vsebin 


\section{Introduction}

Organisations such as the United Nations Educational, Scientific and Cultural Organization (UNESCO), the International Centre for the Study of the Conservation and Restoration of Cultural Property (ICCROM) and others raise the awareness of pupils of the importance of the care of cultural heritage through their programmes (Aslan \& Ardemagni, 2006; Potočnik, 2018). To encourage pupils participation and involvement, a comprehensive heritage preservation education programme should be established, beginning with primary school pupils (ICOMOS, 1987). The American National Council for Preservation Education (1987) launched guidelines for the inclusion of content about the preservation of cultural heritage in primary and secondary schools. The Slovenian National Programme for Culture (2013) states that the contents on heritage preservation need to be incorporated into all levels of the education system. For visual arts education, some specific learning goals for the integration of the contents of preservation education were designed, in accordance with the national curriculum for visual arts education (Potočnik, 2018). In the national visual art curriculum (Kocjančič, 2011), particular attention is devoted to preservation concerns regarding cultural heritage, which considers three main aspects: architecture heritage, landscape heritage, and fine art heritage mostly paintings and sculptures.

In the present study, visual arts teachers were asked to present their views some specific problems consigning the preservation of architecture in the Slovenian countryside and the implementation of heritage preservation concepts (which includes architectural, landscape and fine arts aspects) in visual arts teaching. In recent times, the Slovenian countryside has undergone a considerable change. Identified by researchers, architectural heritage has been inappropriately renovated or replaced by contemporary architecture, which does not take into account the existing architectural heritage; furthermore, it degrades the identity of the Slovenian countryside (Deu, 2009). Experts emphasise that the key lies in education - to date, not enough attention has been paid in the Slovenian school environment to the preservation of architecture in the Slovenian countryside or preservation education in general (Černivec, 2010; Tomšič Amon, 2013). The present research is therefore focused on recognising teachers' preconceptions consigning the preservation of architecture in the Slovenian countryside and the implementation of heritage preservation concepts (which include architectural, landscape, and fine arts aspects) in visual arts teaching, which leads us to compare the results with the current guidelines of preservation education (Potočnik, 2018). 


\section{Theoretical Background}

\section{Comparison between the situation in Slovenia and abroad}

In the Slovenian primary school education system, visual arts education develops an understanding of visual culture, which includes recognising and understanding problems in the environment and considering care for the cultural heritage. Visual arts activities on the primary level (pupils from 6 to 10 years of age) are implemented by primary school teachers, pupils from 11 to 14 years of age are taught by the visual art teachers. Through visual arts experience, pupils can raise awareness and build responsible attitudes in the context of recognising the specific needs of the cultural identity in the Slovenian countryside (Potočnik, 2017a). Visual arts education remains a fundamental subject for raising awareness among pupils about the professions that are responsible for heritage preservation (Potočnik, 2018).

Concepts of heritage preservation education can be found in the visual arts curricula of other countries. Finland's national curriculum emphasises learning about the specifics of architectural heritage and cultural landscape (National core curriculum for basic education, 2004). In the Italian curriculum for the pre-school period and the first five grades of primary school (Indicazioni nazionali per il curricolo della scuola dell' infanzia e del primo ciclo d'istruzione, 2012), much attention is devoted to the creation of appropriate and critical attitudes to cultural heritage with the aim of recognising and respecting it. However, there is no independent school subject designed for this purpose in any nation's school curriculum (Estepa Gimenez, Ruiz, \& Ferreras Listan, 2008). Research (Thornton, 2008) has shown that the contents of heritage preservation education can be reasonably incorporated into various subjects (social sciences, history, national and foreign languages, fine art, music, natural sciences, and mathematics). Research (Estepa Gimenez, Ruiz, \& Ferreras Listan, 2008) conducted among primary and secondary school teachers regarding the inclusion of problems of heritage preservation education shows that teachers who overcome predominating tendencies in thinking and the obstacles associated with concepts consider teacher training to be the key element in doing so.

The school curriculum in some countries has changed through having local cultural heritage embedded within it (Kokko \& Räisänen, 2019; Martínez Rodríguez \& Fontal Merillas, 2020), while simultaneously accommodating many other aspects of the subjects, such as visual arts or science (Angel, Eckford, \& Lowery, 2017). An analysis of textbooks in the Slovenian educational system has shown that local cultural heritage is poorly or insufficiently represented (Kukanja \& Gabrijelčič, 2008). Potočnik (2017) concluded that primary 
school teachers and fine art teachers are favourably inclined towards content related to heritage preservation education; however, they very rarely include this content in their visual arts classes. Other than presenting forms of different kinds of cultural heritage, teachers often do not provide information on suitable and unsuitable interventions in architectural heritage or cultural landscape (Gaskell \& Owen, 2005) or on original materials and their uniqueness (StanleyPrice \& King, 2009), or on professional services (conservators), on legislation, and on the obligations and rights to cultural heritage (Jokilehto, 2005).

\section{Opportunities for heritage preservation education in Slovenian primary schools today}

Heritage preservation education concepts for primary school visual arts activities in Slovenia can be presented through recommended content designed to combine the goals of the national visual arts curriculum and the cotemporary guidelines of preservation education contents (Potočnik, 2018). In the first three-year period of primary school (pupils aged 6 to 8 -years), teachers provide information on cultural heritage, present the differences between natural and cultural heritage, natural and cultural landscape and immoveable and moveable heritage. In architecture, teachers can teach pupils about the first homes (caves) as the first original type of natural shelter, the first buildings and construction materials: soil (clay), wood, stone, straw, baked clay (bricks) (Juvanec, 2006). In this period, teachers should guide pupils to observe their local area and to find local examples of architectural heritage (e.g., in churches, chapels, city squares, homes). In particular, teachers should focus the attention of pupils to observing deteriorating architectural heritage and recognising the importance of a responsible attitude of both the owner and society as a whole towards it and finding simple solutions for the re-use of a particular architectural heritage unit. By introducing pupils to the origins of various materials and to various simple application methods, teachers raise awareness in their pupils about the different materials used in architecture preservation. By teaching them about the transience of such materials, pupils are taught about the importance of their preservation. During the first three-year period, pupils should visit various institutions in charge of the preservation of cultural heritage and learn the basics of heritage concern through various didactic aids.

During the second three-year period of primary school (pupils aged 9 to 11 years) (Potočnik, 2018), teachers can shed light on man-made visual arts creations and provide an in-depth insight into materials, preparation, creation methods, and types of uses. In architecture, pupils learn about the development of space in a house (homestead), in rural and urban environments (Juvanec, 
2006). In this period, teachers encourage pupils to make in-depth comparisons between traditional and contemporary architectural materials, identify opportunities and basic differences enabled by both groups of materials. Pupils should visit institutions in charge of the preservation of cultural heritage and become familiar with the following professions: conservator-restorer, conservator-architect, conservator-landscape architect, and related professions. By creating a visual arts work from traditional materials, they become familiar with them and thus develop a sense of responsibility towards architectural preservation.

In the third three-year period of primary school (pupils aged 12 to 14 years) (Potočnik, 2018), teachers can shed light on conservation practices both locally and abroad (Dvořák, 1916; Jokilehto, 1999). By applying contemporary visual arts practices (performances, textual art, landscape art, installations, etc.), pupils can learn about the preservation of architectural heritage. In architecture, pupils are taught to distinguish between secular (rural, town/city and market-town buildings) and sacred (churches, chapels, plague columns) and secular-sacred (monasteries, presbyteries) heritage; they can distinguish between various types of use: residential or non-residential, changes to the intended use of a facility, describe roofs, builders' joinery, materials, details, and other features used in architectural heritage and compare them to contemporary architecture. Pupils can also become familiar with various cultural landscapes and their distinct architectural heritage, significant differences and specific origins (such as the Bovec House, the Carinthian House, etc.). They use photographs to identify new buildings that match the identity of a specific example of the Slovenian countryside and to describe their characteristics. Teachers can also encourage pupils to observe appropriate and inappropriate interventions in architectural heritage both locally and elsewhere (materials used in restoration procedures, the stylistic configuration of details, increasing apertures, replacing builders' joinery, colours of the façades, additions to facilities, size of facilities, the impact of architecture on the environment subject to existing architecture or distinct cultural landscape, etc.). Illustrations of architectural heritage allow pupils to identify man-adapted measures and ratios (symmetry, rhythm, the Golden Ratio). Photographs of the Slovenian countryside can serve to compare new buildings that match the existing identity of the cultural landscape and establish inappropriate characteristics of new buildings (such as oversized dimensions, imbalanced aperture ratios, inappropriate façade paint, decorative memorials, materials, etc.). In terms of visual arts tasks, they can plan changes to the existing local architecture: reconstructing existing single-family houses ('cubes') into buildings that match the identity of the Slovenian countryside or urban environment (Ivanič, 2012), 
renovating architectural heritage in compliance with contemporary needs, exploring changes to the landscape and architecture by utilising past resources and by documenting the current state. During regular classes, elective subjects, on cultural and technical days, in visual arts afternoon class, and similar., pupils should visit institutions in charge of cultural heritage preservation. They should also become familiar with secondary school and tertiary study programmes for professions engaged in cultural heritage preservation.

In order to unify the understanding of concepts regarding the preservation of architecture in the Slovenian countryside used in this paper, we present, in brief, the primary problems. The Slovenian countryside is distinguished by its transformed natural features and in the historical development of a network of characteristically built structures, consisting of smaller settlements and a different number of independently standing buildings (Deu, 2004). The common rural identity architecture (functional architecture adapted to natural conditions, way of life, cultural influence) is nowadays drowning in a flood of panSlovenian and pan-European urban and building features. New buildings are not taking into account the identity of existing built structures, nor the urban and architectural traditions of local construction. (Deu, 2009). National building legislation takes into account the directions of the sustainable development of Slovenian rural areas and the protection of the cultural diversity of the area. However, unfortunately, the lack of control over construction regulations, inefficient punishment of offenders, lack of qualified experts and low awareness among the population (low level of culture of living) results in the erosion of the identity of the Slovenian countryside (Deu, 2004, 2009). The main issues of interventions in the Slovenian countryside architectural heritage can generally be defined: firstly, by a lack of knowledge (Deu, 2004, 2009) or the purposeful neglect by the owner (Fakin Bajec, 2011). Improper intervention can be made in residential heritage countryside housing by overextending it (by adding extra spaces or floors), inappropriate reduction of or extra doors and windows or similar, which ultimately lead to a less harmonic appearance (Deu, 2009). Problems in the Slovenian countryside from contemporary architecture are mostly large-scale residential buildings with different shapes, unusual colour of tiles, facades, interspersed with balustrades and other decorative adornments, which stand out with their appearance, or universal prefabricated houses (Deu, 2004, 2009; Ivanič, 2012).

Pre-service primary school teachers are not familiarised with contents about heritage preservation in general or architecture preservation directly. Indirectly, they can be informed about architecture and cultural heritage through the course visual arts, or some other social courses, such as society and the 
environment or cultural heritage of the Slovenian people (Presentation book, primary school study programme, 2018). Pre-service visual arts teachers can select a course comprising contents about architecture in general (they design sketches, models, and draws plans for architecture and other) which does not include concepts of preservation heritage in general (Presentation book, visual arts study programme, 2018). The analysis of the pre-service teachers' study programmes shows that pre-service teachers are not exposed to courses in which they can develop their knowledge about preservation.

\section{Research problem and research question}

The main purpose of the present paper is to identify the preconceptions of in-service teachers of visual arts education (implemented at the primary level by primary school teachers and at secondary level by visual arts teachers) about the preservation of architecture in the Slovenian countryside and implementation of these issues in visual arts teaching. The identification of teachers' preconceptions' will aid in understanding their needs for improvement of preservation concepts in visual arts classes.

In this study, we focused on the following research questions:

1. Which preconceptions of in-service teachers about the preservation of architecture in the Slovenian countryside could lead to improvements in the inclusion of preservation education concepts in visual arts classes?

2. Which preconceptions of preservation education about the implementation of these issues in visual arts activities could lead to improvements?

\section{Method}

In this study, a non-experimental and cross-sectional method was used. With the method of free association (Kris, 1992; Sato \& James, 1999), primary school and visual arts teachers' preconceptions about the preservation of architecture in the Slovenian countryside were determined. The method of content analysis (Busch, 2012) of teachers' answers to open-ended questions was used for determining the significance of the implementation concern for the preservation of architecture in the Slovenian countryside, in fine art lessons.

\section{Participants}

A random sample included 125 teachers, 77 (61.6\%) of whom were primary school teachers, and 48 (38.4\%) were fine art teachers at lower secondary school. Among the respondents, the average age was 42.9 years $(S D=9.1$ years) 
and ranged between 25 and 61 years. Visual arts activities from the $1^{\text {st }}$ to the $5^{\text {th }}$ grades at primary school (pupils from 6 to 10 years of age) are implemented by primary school teachers (graduates of a faculty of education, majoring in primary school education). The $6^{\text {th }}$ to the $9^{\text {th }}$ grades (pupils from 11 to 14 years of age) are taught by the visual arts teachers (graduates of a faculty of education, majoring in visual arts education and graduates of an academy of fine arts majoring in painting or sculpture).

\section{Instrument}

A paper-pencil instrument was used to determine teachers' preconceptions. Four different photographs were used, which represent the main problems associated with the preservation of architecture in the Slovenian countryside (Figure 1). Picture 1 represents the owner's lack of knowledge (Deu, 2004, 2009) or purposeful neglect (Fakin Bajec, 2011) with improper intervention (in this case, upgrading the floor above the residential building). Picture 2 presents inappropriate contemporary architecture, represented by a large-scale residential building with different shapes, unusual colour of tiles, facade, interspersed with balustrades and other decorative adornments, which stand out in their appearance (Deu, 2004, 2009). Picture 3 presents appropriate renovation of residential architecture in the countryside, which preserves the external identity, but inside includes all the necessary contemporary conditions of a modern home (Deu, 2004, 2009). Picture 4 represents a countryside area of Slovenia (Štanjel), which is protected as a cultural monument. It can be seen that the preservation of the architectural identity is reflected through the unity or contrasts of the buildings with their size, colour or other features. (Potočnik, 2018).

Teachers were asked to write at least five words under each photo 'whatever comes to their mind - expressing their thoughts, feelings, sensations, memories, wishes and others' (Kris, 1992, p. 212). To determine more information regarding the teachers' preconceptions, an open-ended question: 'What do you think about the preservation of architecture in the Slovenian countryside in general?' was used. To determine the significance of the implementation of this issue in fine art lessons, an open-ended question was used: 'What do you think about the implementation of these issues into visual arts teaching?' 


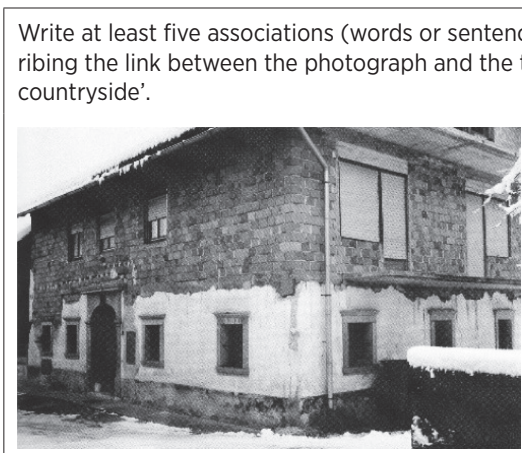

Picture 1

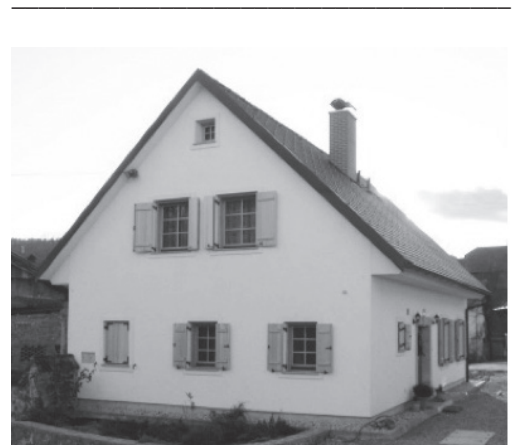

Picture 3

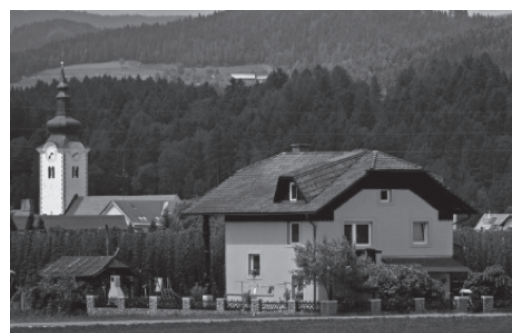

Picture 2

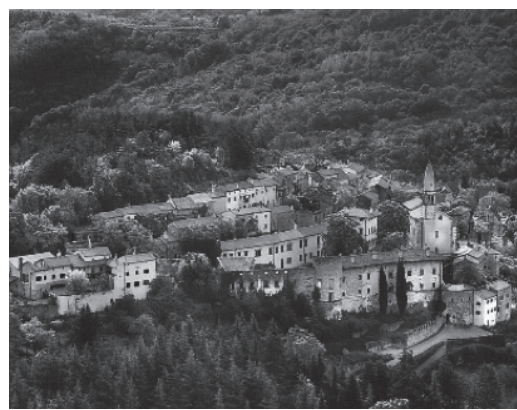

Picture 4

Please express your opinion in the space below. What do you think about the preservation of architecture in the Slovenian countryside in general?

Please express your opinion in the space below. What do you think about the implementation of these issues into visual arts teaching?

Figure 1: Questionnaire to determine preconceptions among primary and visual arts teachers about the preservation of architecture in the Slovenian countryside and the implementation of these issues in visual arts teaching.

\section{Research design}

We determined teachers' differences in preconceptions with the paper-pencil instrument. The random sample included primary schools from all regional units of the Institute of Education of the Republic of Slovenia. 
Headmasters were asked for consent before the survey was carried out. The questionnaires were sent by regular post. A return postage-paid envelope was also enclosed. Of the total 195 questionnaires sent to the teachers, we received 125 (64\%) completed, which is considered to be a good response (Babby, 1998).

In the analysis of free associations, we selected a quantitative approach of content analyses (Sagadin, 1993). Transcriptions of responses were the basis for identifying the main categories, on which basis a coding scheme was developed. In the transcription, codes were identified according to the developed coding scheme and then categorised into specific categories. In each category, the answers were counted and numbered in tables. At the occurrence of a large number of preconceptions that had a low frequency but consisting of a more general (superior) association with high frequency, we combined the associations (Flogaitis \& Angelidou, 2003). If the association appeared at least twice, we included it in the list. The differences in the relative frequencies of specific categories of associations between primary school teachers and fine art teachers were calculated.

To determine the information regarding teachers' preconceptions among primary and visual arts teachers about the preservation of architecture in the Slovenian countryside and the implementation of these issues in visual arts teaching, open-ended questions were designed. In total, we received answers from 29 teachers (23.2\% of all participants), of which 13 were primary school teachers (17.3\%), and 16 were visual arts teachers (37.8\%). All 29 respondents replied to both open-ended questions.

\section{Results}

To determine teachers' preconceptions about preservation of architecture in the Slovenian countryside, we first of all used four different photos (Picture 1, 2, 3, 4) representing issues associated with the preservation (Figure 1). Teachers were asked to list a number of associations for each photo. We present the teachers' preconceptions in Table 1. 
Table 1

Primary school and visual arts teaches' preconceptions about preservation of architecture in the Slovenian countryside

\begin{tabular}{l|c|c|c|c|l}
\hline & \multicolumn{2}{|c|}{$\begin{array}{c}\text { Primary } \\
\text { School }\end{array}$} & $\begin{array}{c}\text { Visual } \\
\text { Arts } \\
\text { Teacher } \\
(77)^{*}\end{array}$ & $\begin{array}{c}\text { Teacher } \\
(48)^{*}\end{array}$ & Dif. \\
\cline { 2 - 6 } & $\mathrm{f}$ & $\mathrm{f} \%$ & $\mathrm{f}$ & $\mathrm{f} \%$ & $\mathrm{f} \%$ \\
\hline
\end{tabular}

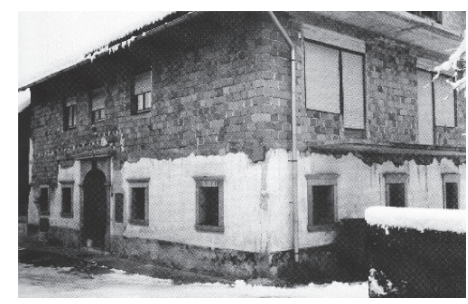

Picture 1: Intervention in architectural heritage (Deu, 2004, 2009).

(Photo: archive of Živa Deu)

Negative responses to intervention

127

Inconsistency, destruction (inadequate, inappropriate), poor aesthetic (ugly, disturbing, negligent), degradation (without identity, truncation), inspection (control, punishment, sanctions, illegal building) and similar.

\begin{tabular}{ll|l|l|l|l|l}
\hline Responses about preservation of architectural heritage in general & 52 & 67 & 37 & 78 & 11 \\
\hline
\end{tabular}

Renovation, adaptation, conservation, building heritage, degradation, monument protection and similar.

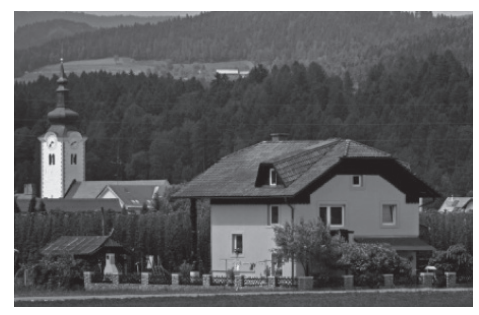

Picture 2: Contemporary architecture in the Slovenian countryside (Deu, 2004, 2009).

(Photo: www.dnevnik.si)

\begin{tabular}{ll|l|l|l|l|l}
\hline $\begin{array}{l}\text { Negative responses to the preservation of the Slovenian } \\
\text { countryside }\end{array}$ & 108 & 140 & 67 & 148 & 8 \\
\hline
\end{tabular}

Unsuitable colour (aggressive, screaming, intrusive facade paint), disparity with the surroundings (landscape, existing architecture), outstanding/striking, poor legislation, inefficiency of professional services, sanctions, lack of taste, poor aesthetic, and others.

\begin{tabular}{l|l|l|l|l|l}
\hline $\begin{array}{l}\text { Positive or neutral responses to the contemporary residential } \\
\text { building in the Slovenian countryside }\end{array}$ & 24 & 31 & 11 & 23 & 8 \\
\hline
\end{tabular}

Old - new / combination of old and new architecture, orderly, in accordance with the surroundings (landscape, existing architecture), beautiful house, and others. 
Picture 3: Intervention in architectural heritage (Deu, 2004, 2009).

\begin{tabular}{|c|c|c|c|c|c|}
\hline $\begin{array}{l}\text { Positive responses to preservation of architecture in the Slovenian } \\
\text { countryside }\end{array}$ & 103 & 134 & 90 & 178 & 53 \\
\hline
\end{tabular}

Renovated house, architectural heritage preservation, well-arranged / beautiful house, sample example of suitable intervention / aggregation of old and new / successful replacement of wornout materials with new ones that follow tradition, cooperation with experts, appropriate plaster and other.

\begin{tabular}{l|l|l|l|l|l}
\hline General architectural associations & 75 & 97 & 44 & 92 & 5 \\
\hline
\end{tabular}

Old (rustic) house, house consistent with the landscape / environment, traditional construction (design, architecture), shutters, proportions, symmetry of the building (windows, entrance) and other.

\begin{tabular}{ll|l|l|l|l|l}
\hline Associations related to emotions and nostalgia & 16 & 21 & 7 & 15 & 6 \\
\hline
\end{tabular}

Hominess, warmth at home, family, tranquillity, memory of old times and other.

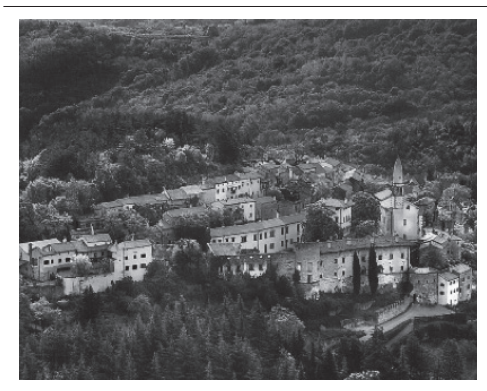

Picture 4: Preservation of architecture in the Slovenian countryside, which is protected as a cultural monument (Deu, 2004, 2009).

(Photo: www.gore-ljudje.net)

\begin{tabular}{l|l|l|l|l|l}
\hline $\begin{array}{l}\text { Associations related to the preservation of countryside and } \\
\text { architecture }\end{array}$ & 96 & 125 & 68 & 142 & 17 \\
\hline
\end{tabular}

Preserving the appearance (initially, without modernisation, unity), coexistence with the environment / given geographical features / nature (coherence, connectivity), unity of construction and materials (stone, roof coverings, white facade), legislation (uniform construction, protection of the environment, control), typical architecture (traditional construction), architectural heritage (building heritage), renovation, architectural monument, settlement with recognisable identity, awareness of people, and others.

\begin{tabular}{l|l|l|l|l|l}
\hline General associations of countryside and architecture & 56 & 73 & 41 & 85 & 12 \\
\hline
\end{tabular}

A compact, clustered village, village, square, landscape, urbanism, architecture, church, castle, walls, landscape architecture, and other.

\begin{tabular}{|c|c|c|c|c|c|}
\hline Associations related to emotions and nostalgia & 15 & 19 & 13 & 27 & 8 \\
\hline \multicolumn{6}{|l|}{ Nice, idyllic, peace, hominess, warmth and other. } \\
\hline \multicolumn{6}{|c|}{$\begin{array}{l}\text { Note. }{ }^{*}=\text { number of teachers that participated in research, } f=\text { number of concepts (associations) } \\
\text { that teachers wrote under the specific photograph and fall into the same category, } f=\text { relative } \\
\text { frequencies of associations in specific category, Dif. = differences in relative frequencies of specific } \\
\text { category of associations between primary school teachers and fine art teachers }\end{array}$} \\
\hline
\end{tabular}




\section{Intervention in architectural heritage (associations under Picture 1)}

\section{Negative response to intervention}

It can be summarised from Table 1 that visual arts teachers expressed $33 \%$ more associations in the category of negative responses to intervention in architectural heritage (Picture 1) than the primary school teachers did. In general, teachers show critical attitudes towards inappropriate interventions and stated terms including 'inconsistency', 'destruction (inadequate, inappropriate)', poor aesthetic (ugly, disturbing, negligent), 'degradation' (without identity, truncation), 'inspection' (control, punishment, sanctions, illegal building) and others.

\section{Responses about the preservation of architecture heritage in general}

The second most commonly mentioned group represents the preconceptions related to the response about the preservation of architecture heritage in general. Most frequently, we perceived terms such as 'renovation', 'adaptation', 'conservation,' 'building heritage,' 'degradation', and 'monument protection. The differences between primary school teachers and visual arts teachers about using general architectural preconceptions of the preservation of cultural heritage are rather low; $11 \%$ more associations were listed by the visual arts teachers.

Considering presented guidelines for the inclusion of heritage education concepts in visual arts activities (Potočnik, 2018) and results obtained by the analysis of teachers' answers, it can be summarised that teachers could pay more attention to deepen their knowledge regarding concepts connected with traditional building materials and authenticity of preservation materials.

\section{Contemporary architecture in the Slovenian countryside (associations under Picture 2)}

\section{Negative responses to the preservation of the Slovenian countryside}

It can be summarised from Table 1 that teachers recognise issues regarding a residential building in the countryside, which stands out with inappropriate dimensions and the colour of the facade. Most often, teachers indicated terms that reflected a negative response to the displayed architecture in the countryside. Differences between negative responses regarding the preservation of the Slovenian countryside are rather low: $8 \%$ more associations were listed by the visual arts teachers. Teachers most often reported associations under the presented photograph, which indicate unsuitable colour (aggressive, screaming, intrusive facade paint), disparity with the surroundings (landscape, 
existing architecture), outstanding / striking, poor legislation, inefficiency of professional services, sanctions, lack of taste, poor aesthetic, and similar.

\section{Positive or neutral responses to the contemporary residential building} in the Slovenian countryside

In addition, teachers were positive or neutral to the photograph of a residential building in the countryside, which stands out with inappropriate dimensions and the colour of the facade. Differences in relative frequencies are higher by $8 \%$ among primary school teachers. Most often, they recorded associations such as 'old-new / combination of old and new architecture', 'orderly', 'in accordance with the surroundings (landscape, existing architecture)', 'beautiful house' and similar.

Taking into account the guidelines for the inclusion of heritage education concepts in visual arts activities presented by Potočnik (2018), teachers should deepen their knowledge regarding concepts of the comparison of traditional architecture (adapted measures and ratios - symmetry, rhythm, the Golden Ratio, etc.) with some characteristics of new buildings, such as oversized dimensions, imbalanced aperture ratio, and similar features.

\section{Intervention in architectural heritage (associations under Picture 3)}

\section{Positive responses to preservation of architecture in the Slovenian countryside}

Table 1 summarises the concepts of teachers on the appropriate intervention in the architectural heritage. Differences in relative frequencies between primary school teachers and visual arts teachers are highest (53\%) in the recorded number of concepts (associations) in this study. Most often, the teachers listed terms such as 'renovated house', 'architectural heritage preservation', 'well-arranged/beautiful house', 'example of suitable intervention / aggregation of old and new/successful replacement of worn-out materials with new ones that follow tradition', 'cooperation with experts', 'appropriate plaster' and similar.

\section{General architectural associations}

According to associations appearing under Picture 3, we were able to determine a second category that contains general architectural preconceptions. Regarding the appearance of preconceptions, differences between primary school and visual arts teachers are rather low (5\%). Teachers using terms like 
'old (rustic) house', 'house consistent with the landscape / environment', 'traditional construction (design, architecture)', 'shutters', 'proportions', 'symmetry of the building (windows, entrance)' and similar.

\section{Associations related to emotions and nostalgia}

We also perceived terms that describe preconceptions related to emotions and nostalgia, which caused us to determine a third category. Regarding the appearance of preconceptions, differences between primary school and visual arts teachers are rather low (6\%). Teachers used terms like 'hominess', 'warmth at home', 'family', 'tranquillity', 'memory of old times' and similar.

As Potočnik (2018) suggested in his guidelines for the inclusion of heritage education concepts in visual arts activities, teachers should think about concepts of re-use of particular architectural heritage unit, preservation of architectural heritage in compliance with contemporary needs and the possibilities of professional services of preservation care.

\section{Preservation of architecture in the Slovenian countryside, which is protected as a cultural monument (associations under Picture 4)}

\section{Associations related to the presented cultural countryside and the preservation of the architectural heritage}

Table 1 summarises the associations of teachers on the preservation of the cultural landscape. Differences in relative frequencies (17\%) were detected among fine art teachers. Most often, teachers mentioned the preconceptions that reflected the presented cultural landscape, concepts of preserving their appearance, coexistence with the environment, given geographical features, and unity in construction.

\section{General associations of countryside and architecture}

In the following, we combined concepts describing the general preconceptions of the landscape and architecture, such as a compact, clustered settlement, architectural heritage, etc., into an independent category. Among fine art teachers, we found $12 \%$ more differences in relative frequencies in comparison to primary school teachers.

\section{Associations related to emotions and nostalgia}

The third category is represented by concepts related to emotions and nostalgia, such as beautiful, idyll, peace, hominess and warmth. Among visual 
arts teachers, we found $8 \%$ more differences in relative frequencies in comparison to primary school teachers.

Summarising teachers' aspects obtained by the instrument used in this study and considering guidelines for the inclusion of heritage education concepts in visual arts activities (Potočnik, 2018), it can be concluded that teachers should also understand concepts of legislation, institutions in charge of conserving and protecting cultural heritage and become familiar with the following professions: conservator-restorer, conservator-architect, conservator-landscape architect, etc.

The second part of the results deals with teachers' preconceptions about the preservation of architecture in the Slovenian countryside, determined by the two open-ended questions, 'What do you think about the preservation of architecture in the Slovenian countryside in general?' and 'What do you think about the implementation of preservation heritage issues into visual arts teaching?' (Figure 1). Qualitative results obtained from the analysis of teachers' responses ( 29 teachers ( $23.2 \%$ of all participants), of which 13 were primary school teachers $(17.3 \%)$, and 16 were fine art teachers $(37.8 \%))$ are presented in Table 2 and Table 3.

Table 2

Preconceptions of primary school teachers and visual arts teachers on the openended question about the implementation of preservation heritage issues into visual arts teaching

\begin{tabular}{lc}
\hline Primary School Teacher & Visual Arts Teacher \\
\hline \multicolumn{1}{c}{ Causes / consequences / condition in general } \\
\hline - We do not do enough for the architectural & - Preserving the architectural heritage of the \\
heritage of the Slovenian countryside of & countryside is in a shameful state. \\
architecture in the Slovenian countryside in & - In the past (even today) countless old \\
general. & houses, farms and other buildings were \\
- Can we compare the cultural landscape in & destroyed. \\
the countryside with us and in England - we & - I support changes in the future of this issue \\
are carrying out a 'terror of heritage'. & in all levels of society. \\
- Preservation of the architectural heritage is a & - There is not much hope in Slovenian society \\
great cost, so it is not accessible to everyone. & for a better future concerning the issues of \\
& the preservation of cultural heritage - aware- \\
& ness of people is too low. \\
\hline
\end{tabular}




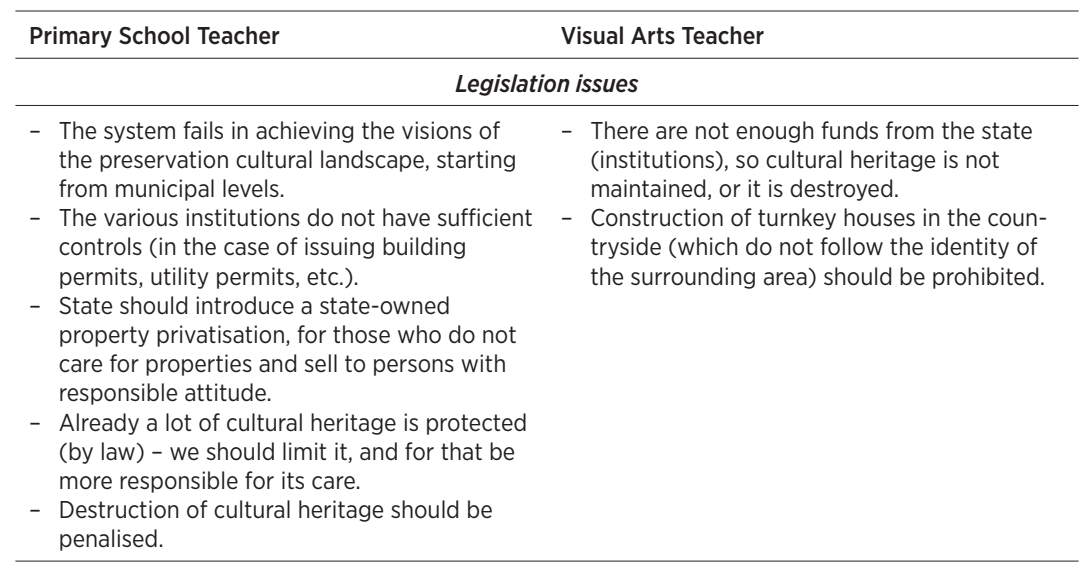

\section{Preconceptions about the preservation of the of architecture in the Slovenian countryside}

\section{Causes, consequences, and condition}

It can be summarised from Table 2 that primary school teachers and visual arts teachers' preconceptions about the preservation of architecture in the Slovenian countryside are similar. Both groups recorded negative conditions in the countryside. Preconceptions include society not doing enough to face these problems in general, the awareness of people being low, and most of the damage has already been done.

\section{Legislation issues}

Statements between primary school teachers and visual arts teachers concerning legislation issues are more critical among primary school teachers. Regarding the poor condition of cultural heritage, primary school teachers see the reasons among preservation services which are inefficient, poor legislation and irresponsibility of owners. Visual arts teachers see problems in financing the preservation of the cultural heritage and insufficient legislation for contemporary architecture in the cultural landscape of the Slovenian countryside.

However, the analysis of teachers' answers to the second questions regarding general preconceptions about the preservation of architecture in the Slovenian countryside showed similar aspects as presented above. As suggested by Potočnik (2018), teachers should pay more attention to good practises from the pupils' living environment: the preservation of architecture in the Slovenian countryside and contemporary architecture's specific origins. 
Table 3

Preconceptions of teachers to an open-ended question about the implementation of the preservation heritage issues into visual arts teaching

\begin{tabular}{|c|c|}
\hline Primary School Teacher & Visual Arts Teacher \\
\hline \multicolumn{2}{|c|}{ The role of the teacher } \\
\hline $\begin{array}{l}\text { - As an adult, gives students an example. } \\
\text { - Strengthens respect for the heritage and the } \\
\text { elderly. } \\
\text { - Sharing the awareness of caring for architec- } \\
\text { tural heritage. } \\
\text { - Plays an important role in raising the aware- } \\
\text { ness towards care of cultural heritage in all } \\
\text { areas. }\end{array}$ & $\begin{array}{l}\text { - Encourages students to think that they need } \\
\text { to protect, respect. } \\
\text { - Raises awareness among students to learn } \\
\text { about the problems of care for local architec- } \\
\text { tural heritage and wider. }\end{array}$ \\
\hline \multicolumn{2}{|c|}{ Personal attitude } \\
\hline $\begin{array}{l}\text { - I am inclined to integrate contents. } \\
\text { - I include content in classes. }\end{array}$ & $\begin{array}{l}\text { - We do not include enough contents in the } \\
\text { lesson. } \\
\text { - It is so important to include problems of } \\
\text { architectural heritage. }\end{array}$ \\
\hline \multicolumn{2}{|c|}{ Teacher training } \\
\hline - We need additional training. & $\begin{array}{l}\text { - We have sufficient knowledge to handle all } \\
\text { content. }\end{array}$ \\
\hline \multicolumn{2}{|c|}{ Role of media, family } \\
\hline $\begin{array}{l}\text { - The society / media / family teach children } \\
\text { the wrong (material) values. }\end{array}$ & $\begin{array}{l}\text { - The role of the media is too weak (do not } \\
\text { report enough on the problems). }\end{array}$ \\
\hline \multicolumn{2}{|c|}{ Preserving national identity, human values } \\
\hline / & $\begin{array}{l}\text { - Young people are strengthened in the } \\
\text { awareness of their own values within the } \\
\text { framework of the identity of the nation, so } \\
\text { they will be able to gain an equal position } \\
\text { within other nations. } \\
\text { - With the care of cultural heritage (architec- } \\
\text { tural, countryside), we take care of affiliation } \\
\text { / value in our place. } \\
\text { - With preservation of cultural heritage } \\
\text { (architectural, countryside), we preserve the } \\
\text { identity of the people. } \\
\text { - We do not care enough about heritage } \\
\text { (architectural, countryside); therefore, the } \\
\text { identity of the people is lost. } \\
\text { - We don't take pride in belonging to our na- } \\
\text { tion - we take everything that is foreign, and } \\
\text { we do not value our own. } \\
\text { - We manage to destroy everything that marks } \\
\text { us as a nation (architecture, countryside). } \\
\text { - By preserving cultural heritage (architecture, } \\
\text { countryside), we preserve human values. } \\
\text { - We are burdened with material goods, dis- } \\
\text { playing prosperity, and everything that is old } \\
\text { is considered to be humiliating, unworthy. } \\
\text { - Constant chasing after the new requires the } \\
\text { destruction of the old. }\end{array}$ \\
\hline
\end{tabular}




\section{Preconceptions of teachers to an open-ended question about the implementation of preservation heritage issues into visual arts teaching}

\section{The role of the teacher}

It can be summarised from Table 3 that comparisons concerning teachers' role in preservation education are similar among primary school and visual arts teachers. Teachers play an important role in raising awareness about the preservation of cultural heritage among pupils. Teachers are examples.

\section{Personal attitude}

Some teachers express personal statements about the inclusion of preservation topics in visual arts lessons. There are no differences in personal attitudes about the inclusion of preservation issues between primary school and visual arts teachers.

\section{Teacher training}

In the conceptions regarding teaching training, differences appeared. Primary school teachers expressed a need for training, but visual arts teachers stated that they have sufficient knowledge to handle all content.

\section{The role of media and family}

Primary school teachers spoke of the problems of society, which focuses on consumerism, and this has consequences among pupils. In contrast, visual arts teachers cited the problems of media, which do not sufficiently report the issues concerning the preservation of the architectural heritage of the Slovenian countryside.

\section{Role of inclusion of contents - preserving national identity and human values}

Only visual arts teachers expressed personal opinions of the significance of dealing with the preservation problems indirectly preserving national identity and human values. They stated that pupils' knowledge of their roots can help them have an equal position among other nations, preserve the identity of our nation and similar. In contrast, visual arts teachers expressed that our national identity is lost among globalisation trends and the lack of a sense of belonging to the nation. Visual arts teachers also expressed conceptions that dealing with preservation issues can influence students' attitudes concerning human values. 


\section{Discussion}

The first research question relates to the preconceptions of in-service teachers about the preservation of architecture in the Slovenian countryside could lead to improvements in inclusion preservation education concepts in visual arts classes. The research shows that teachers recognise inappropriate renovations of architectural heritage in the context of the preservation of the cultural heritage of the Slovenian countryside. Visual arts teachers expressed associations that are more negative. In general, teachers show critical attitudes towards inappropriate interventions in architectural heritage. The research also shows that visual arts teachers use professional terminology more often, but great differences are not detected. Teachers also reported a negative response to inappropriate contemporary architecture, which stands out in its dimensions and the colour of the facade. Differences between negative responses regarding the preservation of the cultural landscape among primary school and visual arts teachers are not great. The research also showed that positive or neutral responses to the inappropriate residential buildings in the Slovenian countryside are also stated by the teachers.

Deu concluded (Petančič, 2011) that the Slovenian culture of living is at a very low level: the general population is environmentally urbanistic and architecturally very uneducated, which can also be seen among conceptions detected in this study.

Teachers responded positively to the preservation of architectural heritage (associations under Picture 3). In this study, the biggest differences in the number of associations were detected among visual arts teachers, regarding positive responses to the proper preservation of the architectural heritage. Differences among participants regarding using general vocabulary are not detectable. The displayed images of the proper preservation of architectural heritage and cultural landscape resulted in a record of terms related to emotions and nostalgia between primary school and visual arts teachers. A romantic nostalgic attitude to cultural heritage is most common, perceived in the form of enthusiasm, usually accompanied by incompetence. This appears in the fields of education and tourism, as well as among Slovenia emigrates (Bogataj, 1992).

Teachers, in general, expressed support for the protection of the cultural heritage, especially when concerning the traditional appearance of the countryside (architecture and countryside). Cultural heritage is perceived as a part of our identity. These findings are consistent with a report on heritage research in Ireland (Simpson, 2007), which showed that people's cultural heritage is an important value that they wish to protect. It represents the identity of their nation, 
and they are aware of the need for thoughtful preservation of the countryside where it is still possible to find architectural heritage typical of a particular area. Teachers are especially critical about the management of architectural heritage in rural areas or outside city centres, because it is not properly looked after by the owners. They are also critical of new buildings in rural areas that do not take the characteristics of traditional architecture into account and, therefore, spoil the cultural landscape. Research has confirmed the existence of these problems, and they have provided guidelines for their effective solutions (Deu, 2008; Fakin Bajec, 2011; Kalčič, 2003). In general, teachers are critical about the state of architectural heritage and its preservation, especially in the countryside. Living in the countryside and life in the old farmhouse symbolised technological backwardness and cultural underdevelopment; by improving their financial position and favourable credit policy in the 1970s, people began to build residential units that did not reflect the characteristic architectural features (Fakin Bajec, 2011).

In addition, teachers are critical of the services responsible for preservation. In their opinion, they are not doing enough and are not credible because they quickly succumb to various pressures. Research in Slovenia shows that, in addition to poor and ineffective control over the implementation of planned interventions and the same ineffective punishment, significant reasons are also the absence of qualified experts and the low awareness of preservation problems among the population (Deu, 2008).

The need for teachers' improvements of inclusion preservation education concepts in visual arts classes should be focused on acquiring knowledge of concepts connected with traditional building materials and the authenticity of preservation materials, differences between contemporary and heritage buildings, focusing in pupils' local environment, re-use of contemporary architecture, concepts of legislation and institutions in charge of protecting cultural heritage.

The second research question deals with preconceptions of preservation education about the implementation of these issues in visual arts activities and could lead to improvements.

It can be concluded that teachers, according to their preconceptions, play a significant role in raising awareness about the preservation education among pupils; this means that a teacher is an example for pupils' experiences of caring about cultural heritage. Teachers with responsible and positive attitudes about the preservation of cultural heritage are examples to every pupil, spreading awareness of the possibilities of revitalising the existing architectural heritage in his setting and beyond, and directing the students to observe their 
surroundings and recognise the needs and specificities of the local cultural heritage. Similar conclusions were obtained by Thornton (2008).

Taking into account teachers' preconceptions about the application of the preservation education into the fine art classes, primary school teachers expressed the need for additional training (Table 3). The need for improvement of primary school teachers' knowledge regarding preservation education has already been illustrated in the study by Potočnik, in which it was concluded that primary school teachers need additional help to incorporate preservation content into their teaching within the visual arts curriculum (Potočnik, 2017a). Visual arts teachers expressed that they are sufficiently competent for implementing these contents into their teaching, but primary school teachers would need more in-service education (Potočnik, 2017a). Primary school teachers are seeking educational resources that would help them deal with the problems the preservation of cultural heritage with concrete examples of visual arts tasks (Potočnik, 2017). The general (Simpson, 2007) as well as the professional public (Aslan, 2006; DeTroyer, 2005) support the idea of dealing with the contents of protection of cultural heritage in class. Research shows that in different countries content related to cultural heritage appears in the visual arts curricula, which enables teachers to deal with the topics related to the protection of the cultural heritage (Taggart, 2004). Many education systems rely solely on primary school teachers, regarding the implementation of visual arts activities at the primary level of schooling (Bamford, 2009). Dealing with these issues in class is challenging; during education at university, such contents are limited; consequently, it is not surprising that primary school teachers lack the relevant knowledge and skills. Primary school teachers spoke about the problem of consumerism in society, which has consequences for pupils. In contrast, visual arts teachers cited the problems of media, which do not sufficiently report the problems concerning the preservation of cultural heritage (architecture, countryside). Only visual arts teachers expressed conceptions of the significance of dealing with the preservation of the cultural heritage (architecture, countryside): preserving national identity and human values. Teachers wrote that pupils' knowledge of their roots can help them to have an equal position among other nations, preserve the identity of our nation and similar.

In contrast, teachers expressed that Slovenia's national identity is being lost within globalisation trends and lacking in belonging to the nation. Visual arts teachers also expressed conceptions that dealing with preservation issues can influence a pupil's attitude concerning human values. As Potočnik (2018) suggested in his guidelines for the inclusion of heritage education, concepts in visual arts activities teachers could pay more attention to deepen their 
knowledge regarding concepts of legislation, institutions in charge of cultural heritage preservation and become familiar with the following professions: conservator-restorer, conservator-architect, conservator-landscape architect, etc.

\section{Conclusion}

Both primary school teachers and visual arts teachers recognise the main interventions concerning the preservation of architecture in the Slovenian countryside. Teachers' agree that preservation issues are relevant and that such contents are needed in the school system (Potočnik, 2017a). Teachers should start from the contents in the curriculum, but when implementing visual arts tasks, they should also include topics concerning the preservation education. With the systematic promotion of critical thinking, permanently raising awareness in pupils about heritage preservation at all stages of the educational process and with planning and implementing visual arts tasks with such contents, teachers can affect the pupils' positive attitude towards cultural heritage preservation (Potočnik, 2018). The research has shown that primary school teachers expressed a need for training. Discussing the contents of cultural heritage, its preservation can result in the formation of social harmonies, the creation of innovations, incentives to political cooperation and development, as well as the exchange of ideas and experience (Alkateb, 2013).

According to the conclusions, some applications for the education process can be suggested. By dealing with the contents of heritage preservation education in visual arts classes and by raising awareness of its meaning, teachers should attempt to value and evaluate the different influences on cultural heritage with pupils. The fact remains that the in-service teachers of visual arts education are left to themselves, according to their abilities, experiences, and beliefs, to choose the issues regarding the preservation education, from rarely accessible literature. The experts of education, and architecture and landscape conservation need to formulate didactic materials for the inclusive issues of preservation education, according to the pupil's development level. More research should be developed in the nature of pupils' understanding of heritage education (level of understanding according to their development, influences of visual culture of perception of space and similar). Particular attention should be given to developing didactic materials for interdisciplinary approaches with other educational subjects at primary level (Pavlin, Vaupotič, \& Čepič, 2013; Potočnik \& Devetak, 2018). More problems regarding the preservation education should be incorporated into pre-service primary and visual arts teachers' education to develop competences to implement these topics into their teaching. 
Some limitations of this study can also be identified, such as the teachers' low response rate to the open-ended questions, so a different type of instrument (e.g., multiple-choice questions) could be applied in future research. Open-ended questions require additional effort from the responder. Through the first question, we were more focused to identify their responses in context of knowledge about issues considering preservation of architecture in the Slovenian countryside. In contrast, participants should present their opinion about these issues answering the second and third questions. Teachers anticipated that they expressed their opinion answering the first question, so they were less motivated to write the answers to these questions. There are no data about what heritage preservation professionals' opinions are about the inclusion of preservation issues into the educational system, so these issues could be addressed in future studies by applying in-depth interviews. It is also essential to emphasise that similar studies ought to be conducted with pre-service teachers, high school teachers, and kindergarten teachers so that a more in-depth picture of preservation education issues could be developed.

\section{References}

Alkateb, M. (2013). Non-traditional education using cultural heritage: A case study from Syria. International Journal of Education through Art, 9(2), 189-04.

Angel, V., Eckford, L., \& Lowery, L. (2017). Developing a community orientation through a focus on local heritage and environment. In D. Leat (Ed.), Enquiry and project based Learning. Routlege. Aslan, Z., \& Ardemagni, M. (2006). Introducing young people to the protection of heritage sites and historic cities. UNESCO-ICCROM.

Babby, E. (1998). The practise of social research (8th ed.). Wadsworth Publishing Company. Bamford, A. (2009). Arts and cultural education in Iceland. Ministry of Education, Science and Culture. Bogataj, J. (1992). Sto srečanj z dediščino na Slovenskem [Hundred meetings with heritage in Slovenia]. Prešernova družba.

Busch, C. (2012). Content analysis. Colorado State University. https://writing.colostate.edu/guides/ guide.cfm?guideid $=61$

Černivec, U. (2010). Pogovor z dr. Živo Deu o skrbi za arhitekturno dediščino na Slovenskem [Conversation with Dr Živo Deu on the care of architectural heritage in Slovenia]. http://www. slonep.net/prenova-in-obnova/?view=novice $\&$ direct $=10779$

Deu, Ž. (2008). Varstvo identitetne podobe slovenskih kulturnih krajin [Protection of the identity of Slovenian cultural landscapes]. In M. Kitek Kuzman (Eds.), Gradnja z lesom [Construction in wood] (pp. 226-231). Biotehniška fakulteta.

Dvoř́k, M. (1916). Katechismus der Denkmalpflege [Catechism of the preservation of monuments]. R. M. Rohrer. 
Estepa Gimenez, J., Ruiz, R. M. A., \& Ferreras Listan, M. (2008). Primary and secondary teachers' conceptions about heritage and heritage education: A comparative analysis. Teaching and Teacher Education, 24, 2095-2107.

Fakin Bajec, J. (2011). Ustvarjanje kraške kulturne dediščine med teorijo in prakso [Creating karst cultural heritage between theory and practice]. AR: arhitektura, raziskave, 3, 59-62.

Flogaitis, E., \& Agelidou, E. (2003). Kindergarten teacher's conceptions about nature and the environment. Environmental Education Research, 9(4), 462-478.

Gaskell, P., \& Owen, S. (2005). Historic farm buildings: Constructing the evidence base. University of Gloucestershire.

Hankins, S. C. (1997). Focus on 2000: A heritage education perspective. National Centre for preservation Technology and Training. https://www.ncptt.nps.gov/blog/focus-on-20oo-a-heritageeducation-perspective-1997-08/

ICOMOS. (1987). International charter for the conservation of historic towns and urban areas. http:// www.icomos.org/charters/towns_e.pdf

Indicazioni nazionali per il curricolo della scuola dell'infanzia e del primo ciclo d'istruzione [National indications for the curriculum of the school of education and the first cycle of instruction] (2012). http://www.indicazioninazionali.it/documenti_Indicazioni_nazionali/indicazioni_nazionali_ infanzia_primo_ciclo.pdf

Ivanič, M. (2012). Svet je prenasičen: oživljanje in posodabljanje obstoječe arhitekture je današnja nujnost [The world is oversaturated: revitalizing and modernizing existing architecture is a necessity today]. Mladina, $17(18), 68-72$.

Jokilehto, J. (1999). History of architectural conservation. Butterworth.

Jokilehto, J. (2005). Definition of cultural heritage. References to documents in history. ICCROM

Working Group 'Heritage and Society'. http://cif.icomos. org/pdf_docs/Documentsonline/

Heritagedefinitions.pdf

Juvanec, B. (2006). Kultura bivalnega okolja: arhitektura, uvod, teorija [Culture of living environment: architecture, introduction, theory]. Pedagoška fakulteta.

Kalčič, I. (2003). Identiteta slovenske stanovanjske arhitekture [Identity of Slovenian residential architecture]. AR: arhitektura, raziskave, 3(1), 24-29.

Kocjančič, N. (2011). Učni načrt. Program osnovna šola [Curriculum. Primary school programme]. Ministrstvo za šolstvo in šport: Zavod RS za šolstvo.

Kokko, S., Räisänen, R. (2019). Craft education in sustaining and developing craft traditions. Techne serien - Forskning i Slöjdpedagogik och Slöjdvetenskap, 26(1), 27-43.

Kris, A.O. (1992). Interpretation and the method of free association. Psychoanalytic Inquiry 12(2), 208-224.

Kukanja-Gabrijelčič, M. (2008). Lokalna zgodovina pri družboslovnih predmetih v osnovni in srednji šoli. Vloga, pomen in zastopanost lokalne zgodovine v slovenskem šolskem prostoru [Local history in social science subjects in primary and secondary school. The role, significance and representation of local history in the Slovenian school environment]. http://www.mizs.gov.si/fileadmin/mizs.gov.si/ 
pageuploads/podrocje/razvoj_solstva/crp/2008/crp_V5_0237_porocilo_p2.pdf Martínez Rodríguez, M., \& Fontal Merillas, O. (2020). Dealing with heritage as curricular content in Spain's Primary Education. The Curriculum Journal, 31(1), 77-96.

National core curriculum for basic education. (2004). Finnish national board of education. http:// www.oph.fi/download/47673_core_curricula_basic_education_4.pdf

National Council for Preservation Education. (1987). A heritage at risk: A report on heritage education $(K-12)$. University of Vermont Historic Preservation Program and the National Council for Preservation Education.

Pavlin, J., Vaupotič, N., \& Čepič, M. (2013). Liquid crystals: A new topic in physics for undergraduates. European journal of physics, 34(3), 745-761.

Petančič, S. (2011). Predavateljica in arhitektka: Naše prebivalstvo je arhitekturno neizobraženo [Lecturer and architect: Our population is architecturally uneducated]. http://www.delo.si/druzba/ panorama/predavateljica-in-arhitektka-nase-prebivalstvo-je-arhitekturno-neizobrazeno.html Potočnik, R. (2017). Effective approaches to heritage education: Raising awareness through fine art practice. International Journal of Education Through Art, 13(3), 285-294.

Potočnik, R. (2017a). Implementing contents of conservation and protection of cultural landscape in fine art classes. Croatian Journal of Education, 19(3), 137-155.

Potočnik, R. (2018). Heritage preservation education in primary school fine art activities. http://www. arteducation.sk/publikacie-studie-clanky/detail/heritage-preservation-education-in-primary-schoolfine-art-activities//

Potočnik, R., \& Devetak, I. (2018). The differences between pre-service chemistry, fine art, and primary education teachers regarding interest and knowledge about fine art materials. Center for Educational Policy Studies Journal, 8(4), 109 -130.

Presentation book, primary school study programme. (2018). https://www.pef.uni-lj.si/fileadmin/ Datoteke/Studijski_programi/Predstavitveni_zborniki/Zborniki_18-19/Predstavitveni_zbornik_-_ Razredni_pouk_-_2018-2019.pdf

Presentation book, visual arts study programme. (2018). https://www.pef.uni-lj.si/fileadmin/ Datoteke/Studijski_programi/Predstavitveni_zborniki/Zborniki_18-19/Predstavitveni_zbornik_-_ Likovna_pedagogika_-_2018-2019.pdf

Sagadin, J. (1993). Kvalitativna analiza podatkov pri študiji primera [Qualitative analysis of data in a case study]. Sodobna pedagogika, 44(3/4), 115-123.

Sato, M., \& James, P. (1999). Nature and environment as perceived by university students and their supervisors. International Journal of Environmental Education and Information, 18(2), 165-172.

Simpson, K. (2007). Valuing heritage in Ireland. The Heritage Council.

Stanley-Price, N., \& King, J. (2009). Conserving the authentic: Essays in honour of Jukka Jokilehto. ICCROM International Centre for the Study of the Preservation and Restoration of Cultural Property.

Slovenian National Programme for Culture. (2013). Ministrstvo za izobraževanje, znanost, kulturo in šport. http://www.mizs.gov.si/fileadmin/mizs.gov.si/pageuploads/Obvestila/Kultura/NPK2013_2016.pdf 
Taggart, G. (2004). Curriculum and progression in the arts: An international study. Qualifications and Curriculum Authority.

Thornton, L. (2008). Current trends in historic preservation education at the primary and secondary school levels. Preservation Education \& Research, 1(1), 67-76.

Tomšič Amon, B. (2013). Visual Art Education: Between Spatial Sustainable Development and the Image of Architecture. Center for Educational Policy Studies Journal, 3(1), 79 -96.

\section{Biographical note}

Roвert Potočnik, $\mathrm{PhD}$, is an assistant professor of fine art education at the Faculty of Education, University of Ljubljana, Slovenia. His research interests include didactics of fine art education, preservation education and cultural heritage conservation. 